\title{
CULTURE AND BUSINESS ETHICS - A COMPARATIVE PERSPECTIVE
}

\author{
Florin Lucian Isac, Ph.D., Associate Professor \\ „Aurel Vlaicu” University of Arad, Faculty of Economics \\ florinisac72@yahoo.com \\ Eugen Florin Remes, Ph.D., Associate Professor \\ „Vasile Goldis” Western University of Arad, Faculty of Economics \\ eugenremes@yahoo.com
}

(Received June 2017; Accepted September 2017)

\begin{abstract}
Accelerating growth in business globalization places managers in an international environment with more ethical challenges.

Ethical principles that govern businesses in a particular culture may not match with the conditions, norms and customs of other cultures.

The article aims to examine comparatively the role of culture in explaining ethical issues and dilemmas in organizations.

Treating the issue of business ethics in companies nowadays offer different perspectives depending on the influence of the cultural context of countries where these companies operate.

Each cultural context shows its specificity, in addition to legal regulations, customs, habits or moral issues, which deserve to be highlighted in a paper on how to conduct business from an ethical perspective.
\end{abstract}

Key words: ethics, business, culture, multinational corporations

JEL Classification: M14, F23

\section{Introduction}

Business ethics is a subject that increasingly concerns both the practitioners and the academic community. In the context of globalization, the development and expansion of multinational companies in many countries have put issues of ethics and social responsibility into a new perspective for international management researchers.

The theoretical approach of ethics in international affairs has taken place quite late, especially due to misperceptions that the moral condition can only be attributed to individuals, and large corporations could only be associated with legal and nonethical issues (Crăciun, Morar, and Macoviciuc, 2005).

The business strategy of multinational corporations includes the ethical component in many ways: as a social responsibility of the company for the host and home countries; as an attitude towards the other participants in the world economic circuit (governmental international bodies, third states, non-governmental 
organizations) (Popa and Filip, 1999). One of the main problems that companies can encounter, especially in developing nations, is the potential conflict between their customs, norms and conditions and their own ethical standards. Thus, a manager working in a multicultural environment will have to manage a series of ethical issues about how to conduct business in different cultures and how to provide the necessary guidance for employees to properly address these dilemmas. As the process of globalization intensifies and even if there are values that have universal vocation, business ethics is a concept that is influenced by the cultural context.

\section{The role of culture}

One of the most well-known and communicated definitions of culture is "collective mind programming ... which distinguishes the members of a group or a category from the other people" (Hofstede, Hofstede and Minkov, 2012). This definition suggests that patterns of thinking differ according to national culture, and individuals use these models to interpret the environment and direct their own actions. Culture, regarded by Hofstede as "mind software", is taught and transmitted from one generation to the next, integrating elements such as language, religion, customs, morals, and law. However, cultural programs are not as easy to "install" as the informational ones to decrypt the hidden meanings of another culture, requiring a spirit of observation, study, and abandoning the idea of superiority of one's own culture.

Culture was approached as one of the determinants of ethical judgments in models of ethical behavior proposed by Bartels (1967) or by Hunt and Vitell (1986). Also, culture-influenced factors such as religious laws, values, or beliefs have been identified as having a key role in ethical decision-making situations (Bartels (1967), in Carroll and Gannon (1997)). Carroll and Gannon (1997) have proposed a model of culture influence on managers' ethical behaviors. The model is based on the analysis of the origins of culture, considered to be history, resources and geographical positioning. Italy, which is a unified country only since 1861, has developed a fear of foreigners who were assigned by their leaders to infiltrate the Italians' cultural groups, avoiding the payment of taxes to them. These historical factors still play an important role today in the ethical practices of Italians who tend to trust only people in their inner group and in some cases to violate tax laws. Natural resources can also influence managerial ethics. The precariousness of Japan's natural resources for example has stimulated hard work for survival, which involved a joint effort in local communities. Thus, the value of harmony in the work of the common good has developed, and behaviors attempting to destroy this sense of harmony have often been described as unacceptable or unethical. 
Isac F.L., Remes E.F. (2017)

Culture and business ethics - a comparative perspective

The second element of the model is national culture itself, with two overlapping aspects: managerial practices related to different ethical aspects and the essential values that lead to differences between these practices. The next element consists of the main and secondary elements that influence values and behaviors. Parental influence and socialization are primary influences, and laws, organizational culture, and human resource management systems are secondary influences. Secondary influences not only reflect culture but exert independent pressure on individuals to behave in a certain way (Carroll and Gannon, 1997).

In order to understand how collective mental programming can lead to ethical misunderstandings, we will focus on two cultural dimensions proposed by Geert Hofstede, considered to be relevant to understanding ethics in international affairs: Individualism vs. Collectivism and Power Distance.

Individualism is characteristic of "societies where links between individuals are weak: everyone expects to take care of themselves and of their immediate family" and collectivism characterizes "the societies in which people are born in strong and united internal groups and who throughout their lives continue to protect them in return for unconditional loyalty" (Hofstede, Hofstede and Minkov, 2012). Members of individualist cultures will conform only to defend or protect their personal interests, while members of collectivist cultures will accept organizational demands due to the internalization of group rules. Because in collectivist cultures, the basis for human motivation is different, individual rewards or punishments used in ethics management in the USA may prove inappropriate (Weaver, 2001). In their attempt to manage ethical issues, many companies have formal reporting systems that encourage employees to report the deviations they see. Such a system may not be accepted in collectivist cultures, which they consider too impersonal and too oriented to accuse an individual who will eventually be ashamed (Treviňo and Nelson, 2011). Organizations in collectivist cultures will seek to solve ethical problems rather by organizational culture management and less by formal structure.

The power distance is defined as "the extent to which less powerful members of institutions and organizations in a country expect and accept that power is unevenly distributed" (Hofstede, Hofstede and Minkov, 2012). If power and responsibility remain at the level of top management, ethical initiatives that, in North American style, will focus on all members of the organization can be ignored or can result in dysfunctional results. Multinational companies operating in cultures with high power distance are advised to focus its management activities on elites organizational ethics, unlike egalitarian approach promoted in North American practice (Weaver, 2001). Cultures with low power distance are inclined not to focus on status or social class differences; Employees accept the boss's power due 
to his expertise and less because of his authority. Thus, employees of such cultures will be inclined to question the authority of the boss or to denounce the case of an ethical manager (Treviňo and Nelson, 2011).

Assumptions can also be made on the influence of other cultural dimensions on ethics practices. Thus, ethical initiatives can have legitimacy that is questioned in cultures with masculinity, unless they contribute to achieving performance. In feminine cultures, ethical non-punitive programs may have greater legitimacy. We might expect that countries with a predominantly feminine profile promote codes of ethics in business more than those with a masculine profile, which is even contradicted by the USA, a country with a strong masculinity, which clearly leads in promoting ethical business codes (Crăciun, Morar and Macoviciuc, 2005). Formal codes and review procedures are consistent with high avoidance of uncertainty, while ethics management through anonymous reporting systems, informal methods, and manipulation of organizational culture can be problematic in such situations (Weaver, 2001).

\section{National cultural differences and ethics in business}

\subsection{Business Ethics in North America}

At first glance, the geographic proximity of the three North American countries (USA, Mexico and Canada) might suggest similarities in ethical practices between them. Differences, however, are important.

Table 1. Comparison of the Contexts and Characteristics of Corporate Governance and Business Ethics in North America

\begin{tabular}{|c|c|c|c|}
\hline Countries & Mexic & USA & Canada \\
\hline Economy & $\begin{array}{l}\text { Moderate; stabilizing low } \\
\text { per capita GDP }\end{array}$ & $\begin{array}{l}\text { Large and robust; high } \\
\text { real per capita GDP and } \\
\text { productivity }\end{array}$ & $\begin{array}{l}\text { Moderate; persistent } \\
\text { unemployment }\end{array}$ \\
\hline Legal system & $\begin{array}{l}\text { Civil; codified rules; } \\
\text { sluggish judiciary }\end{array}$ & $\begin{array}{l}\text { Common; case law; } \\
\text { strong civil system }\end{array}$ & $\begin{array}{l}\text { Common; case law; } \\
\text { efficient judiciary }\end{array}$ \\
\hline $\begin{array}{l}\text { Economic } \\
\text { regulation }\end{array}$ & $\begin{array}{l}\text { Comply or explain; } \\
\text { reforms underway }\end{array}$ & $\begin{array}{l}\text { Rules; Sarbanes-Oxley } \\
\text { backlash }\end{array}$ & $\begin{array}{l}\text { Comply or disclose; } \\
\text { decentralized }\end{array}$ \\
\hline $\begin{array}{l}\text { Corporate } \\
\text { governance }\end{array}$ & $\begin{array}{c}\text { Concentrated, family } \\
\text { control; poor shareholder } \\
\text { protection } \\
\end{array}$ & $\begin{array}{c}\text { Dispersed ownership; } \\
\text { shareholder-focused } \\
\text { board }\end{array}$ & $\begin{array}{l}\text { Concentrated; family } \\
\text { control; poor } \\
\text { shareholder protections }\end{array}$ \\
\hline Corruption & $\begin{array}{l}\text { Pervasive; in fundamental } \\
\text { reform }\end{array}$ & Low to moderate & $\begin{array}{c}\text { Low; minimal } \\
\text { discretion }\end{array}$ \\
\hline $\begin{array}{l}\text { Corporate } \\
\text { governance }\end{array}$ & Pemex, TV Azteca & $\begin{array}{c}\text { Enron; WorldCom; Tyco; } \\
\text { Adelphia }\end{array}$ & Livent; YBM Magnes \\
\hline
\end{tabular}

Source: Verstegen Ryan, L., (2005), Corporate Governance and Business Ethics in North America: The State of the Art, Business \& Society, Vol. 44., No. 1, March, p. 41 
Isac F.L., Remes E.F. (2017)

Culture and business ethics - a comparative perspective

Of the three countries, the USA is considered the country in which business ethics was born.

American society was influenced by Protestantism, which formulated a series of religious teachings linked to economic life (Weber, 1993).

In Weber's conception, Protestant ethics calls for diligence, self-control and sobriety, self-confidence and perseverance, and poverty was associated with lack of willingness to work (Ionescu, 1997). In the $20^{\text {th }}$ century we noticed the existence of three waves of business ethics in the USA (Iamandi, 2012):

- The first wave, characteristic of the period 1920-1930, brings to the fore the role of religious ideologies in business;

- The second wave (1950-1960) is marked by the introduction of business ethics courses in USA universities, and the social responsibility of organizations is becoming a matter of much debate;

- The third wave, which has occurred in all Western countries since 2000 as a result of scandals generated by large corporations' frauds.

The vast majority of large USA companies hold codes of ethics, about $78 \%$ according to a 1995 study. Company size and type of industry in which it operates have been linked to the existence of a distinct code of ethics (Hood and Logsdon, 2002).

Although the level of business risk is relatively low in the USA, the American "business" is perceived as corrupted to some extent. Numerous scandals shook the USA capital market, perhaps the most well-known case of Enron, where CEO Kenneth Lay and young financier Andrew Fastow built a cartoon empire with "creative accounting", but also the WorldCom or Adelphia cases. Many of these scandals were caused by so-called problem of "agency" between management and shareholders, directors themselves becoming shareholders (Verstegen Ryan, 2005). Hood and Logsdon (2002) formulated some hypotheses about the implications of culture in business ethics in North America.

Thus, they have estimated that Mexican firms are less likely to have formal codes of ethics than the USA and Canada, due to masculinity, greater power distance, and intuitive problem-solving.

They also formulated the hypothesis that Mexican firms are more likely to bribe public officials than Canadian or USA officials because of high levels of power distance, avoidance of uncertainty and collectivism, but also because of the belief that people are good and evil. Third, they considered that Mexican firms are more likely to treat employees at the base of the organizational pyramid better than companies in the USA or Canada, due to collectivism, avoidance of high uncertainty and paternalism, and a more common attitude towards work. 


\subsection{Business Ethics in East and Southeast Asia Business Ethics in Japan}

Japanese ethics are strongly linked to strictly define religious and social values: groups and not individuals have their own spirit, connected to reality - a collectivist, traditionalist society, social status by position, company care for employees (Iamandi, 2012). It is part of the individual's spiritual baggage: Confucianism promotes justice, fairness and harmony based on loyalty. The Westerners had difficulty in understanding the functioning of a society based on morality rather than just. By moral, in the context of the Japanese, we should understand "the art of living in a group, which seeks to prevent the aggressiveness and to defend the long-term interest through common rules, actions and values based on experience and truth, inspired by education and insured by a social control" (Burduş, 2004).

Business ethics in Japan should be addressed in a very comprehensive way by including different levels of economic activity and many moral agents (individuals, families, clans, small groups, corporations, multinational firms, government).

Table 2. History of Business Ethics in Japan

\begin{tabular}{|c|l|}
\hline Stage & \multicolumn{1}{|c|}{ Characteristics } \\
\hline Prior to the 1960s & $\begin{array}{l}\text { The concept of social responsibility for business was not taken seriously by } \\
\text { the Japanese business community; Priority given to economic growth. }\end{array}$ \\
\hline $\begin{array}{c}\text { Half of the 1960s - } \\
\text { Half of the 1970s }\end{array}$ & $\begin{array}{l}\text { The emergence of social issues in business; Major changes in legal and } \\
\text { administrative systems, as well as in consumer movements; The } \\
\text { involvement of KEIDANREN and Keizai Doyukai in building a "welfare } \\
\text { society"; There is no systematic attention given to the theory of ethics. }\end{array}$ \\
\hline $\begin{array}{c}\text { The second half of the } \\
1970 \mathrm{~s}\end{array}$ & $\begin{array}{l}\text { Restructuring corporations; At the end of 1973, due to the oil crisis, the } \\
\text { efforts of corporations to achieve social responsibility failed; The Japanese } \\
\text { focused on streamlining the organizational structure that ensured their } \\
\text { survival. }\end{array}$ \\
\hline $1980 \mathrm{~s}$ & $\begin{array}{l}\text { "The bubble economy": achieving high levels of performance and } \\
\text { prosperity; Collaborative and flexible relationships between management } \\
\text { and employees, financial institutions and customers, regulatory and industry } \\
\text { institutions; The business community begins to think that Japanese } \\
\text { management is not only effective but also ethical }\end{array}$ \\
\hline $1990 \mathrm{~s}$ & $\begin{array}{l}\text { Developing Business Ethics as a New Field: Two Trends in Japanese } \\
\text { Business Ethics: Positive and Passive; The most important is the passive, } \\
\text { determined by a series of scandals. }\end{array}$ \\
\hline
\end{tabular}

Source: Synthesis by authors from Taka, Iwao, (1997), Business Ethics in Japan, Journal of Business Ethics, 16, pp. 1500-1502

There are differences between the definition of ethical issues in the USA and Japan, as shown in Table 3.

DE GRUYTER OPEN
Studia Universitatis "Vasile Goldis" Arad. Economics Series Vol 27 Issue 3/2017 ISSN: 1584-2339; (online) ISSN: 2285 - 3065 
Isac F.L., Remes E.F. (2017)

Culture and business ethics - a comparative perspective

Table 3. Definition of ethical issues. Differences between the USA and Japan

\begin{tabular}{|l|l|}
\hline \multicolumn{1}{|c|}{ USA } & \multicolumn{1}{|c|}{ Japan } \\
\hline Legalist approach: based on regulations and rules & $\begin{array}{l}\text { Implicit approach: Ethical standards are learned } \\
\text { and assumed in the process of social practice; } \\
\text { They are transmitted as usages }\end{array}$ \\
\hline $\begin{array}{l}\text { Explicit approach: rules are written in codes of } \\
\text { conduct and lists of principles }\end{array}$ & $\begin{array}{l}\text { Particularistic approach: compliance with rules } \\
\text { depends on the position and personal } \\
\text { relationships of individuals, the rules apply } \\
\text { according to circumstances }\end{array}$ \\
\hline $\begin{array}{l}\text { Universalist approach: the rules apply equally to } \\
\text { everyone }\end{array}$ & $\begin{array}{l}\text { Collectivist approach: morality is defined more } \\
\text { in terms of interdependence than independence } \\
\text { of individuals }\end{array}$ \\
\hline $\begin{array}{l}\text { Individualist approach: Ethical decisions are } \\
\text { personal and they involve individual } \\
\text { responsibility }\end{array}$ & $\begin{array}{l}\text { Consensual approach: moral values are defined } \\
\text { by community norms and not by individual's } \\
\text { choices }\end{array}$ \\
\hline
\end{tabular}

Source: Popa I., Filip R., Management internaţional, Ed. Economică, Bucureşti, 1999, p.271

In South Korea, until 1990, values related to integrity, human relations and cooperation have been positioned as essential factors for the ideal human type (Cho, 2009). Korean society emphasizes the importance of acting in accordance with the interests of the company or the manager or owner of the company, and Korean managers seem to be impelled by "group selfishness" or "collectivism" (Choi and Nakano, 2008), an aspect that may signal a positive ethical culture if we think about the loyalty they develop to the company.

One of the major changes in the global economy of the 21st century is the positioning of the Chinese economy as one of the strongest in the world. In such emerging economies, the level of business uncertainty is higher than in mature economies. These issues of uncertainty can be solved through the "Guanxi" social networks and the ethical behavior associated with them (Tam, 2002). Chaterjee and Pearson (2003, p.206) have defined "guanxi" as "a deep rooted socio-cultural phenomenon which enhances social harmony, maintains correct relationships and addresses the sensitive issue of face, a reciprocal obligation to respond to requests for assistance". Guanxi practice is rooted in Confucian concepts of fulfilling rolebased duties, respect for parents, cultivating mutual support relationships between stronger and weaker individuals. Guanxi plays an important role in China's global value system, allowing managers to obtain the necessary resources within the group. Ethical practices in China's business organizations are based on cultural values such as paternalism, collectivism and guanxi, reduced focus on formal behavioral contracts or codes, an important role for informal support networks; In ethical decision-making situations, employees and managers will rather use particularistic and situational criteria than universal ones (Ardichvili et al., 2012). 
Isac F.L., Remes E.F. (2017)

Culture and business ethics - a comparative perspective

Table 4. Evolution of Chinese Business Ethics Infrastructure

\begin{tabular}{|c|c|c|c|}
\hline Stage & Source of change & $\begin{array}{l}\text { Practice } \\
\end{array}$ & Theory \\
\hline Pre-1978 & Need for modernization & $\begin{array}{c}\text { Class struggle was the } \\
\text { key, not economic activity }\end{array}$ & Marxist Theory \\
\hline $1978-1984$ & $\begin{array}{c}\text { Need for de- } \\
\text { collectivization, } \\
\text { decentralization and } \\
\text { diversification }\end{array}$ & $\begin{array}{l}\text { Academic debates on the } \\
\text { need for business ethics }\end{array}$ & $\begin{array}{l}\text { Governance (accounting, } \\
\text { taxation, finance and } \\
\text { government involvement) } \\
\text { based on Chinese culture }\end{array}$ \\
\hline 1984-1994 & $\begin{array}{l}\text { Communist party: } \\
\text { "Socialism with chinese } \\
\text { characteristics" }\end{array}$ & $\begin{array}{l}\text { Social and economic } \\
\text { reforms and their effects } \\
\text { on rural business activity }\end{array}$ & $\begin{array}{l}\text { Basic business ethics theory } \\
\text { including commerce, } \\
\text { economics and management }\end{array}$ \\
\hline $1994-2001$ & $\begin{array}{c}\text { Business ethics } \\
\text { emerged from domestic } \\
\text { economic reforms }\end{array}$ & Socialist market economy & $\begin{array}{l}\text { Business ethic theory built } \\
\text { around Socialist thought }\end{array}$ \\
\hline $\begin{array}{l}2001- \\
\text { present }\end{array}$ & $\begin{array}{l}\text { The need for China to } \\
\text { comply with WTO rules }\end{array}$ & $\begin{array}{l}\text { Adaptation of business } \\
\text { ethics to WTO standards } \\
\text { with a Chinese twist }\end{array}$ & $\begin{array}{l}\text { A move to a more Western } \\
\text { theory of business ethics with } \\
\text { questions as to its limits and } \\
\text { implementation }\end{array}$ \\
\hline
\end{tabular}

Source: Berger R., Herstein R., (2014), The Evolution of Chinese Business Ethics, Management Research Review, Vol. 37, No. 9, p. 785

\subsection{Business Ethics in Europe}

The historical and cultural differences between most European countries are so significant that it is impossible to generalize about business ethics approaches in Western Europe (Mele, 2008). Compared to the USA, Continental Europe puts less emphasis on corporate codes of ethics, but rather insists on strengthening the legal framework for business conduct. A comparative study of the differences in business ethics in the USA and Germany by Palazzo (2002) revealed that German firms are less willing to introduce formal ethical programs than those in the USA, and German managers have a particular approach in this field.

The first European Business Ethics Research Center was set up at the current University of Sankt Gallen in Switzerland in 1983 and the first business ethics department in the Netherlands at Nyenrode Universiteit in the Netherlands (Iamandi, 2012). In 1987 EBEN (European Business Ethics Network), an organization with more than 1200 members from 40 countries, was founded and its development continues (Van Liedekerke and Dubbink, 2008). The themes addressed in European business ethics are mainly related to the rights and obligations of employees, customers, shareholders and suppliers, the impact of industrial activities on the environment, advertising and marketing practices, ethics of mergers and hostile acquisitions.

DE GRUYTER OPEN 
Isac F.L., Remes E.F. (2017)

Culture and business ethics - a comparative perspective

\begin{tabular}{|c|c|c|c|}
\hline \multicolumn{4}{|c|}{ Table 5. Regional differences from a a business ethics perspective } \\
\hline $\begin{array}{c}\text { Who is responsible for } \\
\text { ethical conduct in } \\
\text { business? }\end{array}$ & $\begin{array}{c}\text { Social control by the } \\
\text { collective }\end{array}$ & The individual & Top management \\
\hline $\begin{array}{c}\text { Who is the key actor in } \\
\text { business ethics? }\end{array}$ & $\begin{array}{c}\text { Government, trade } \\
\text { unions, corporate } \\
\text { associations }\end{array}$ & The corporation & $\begin{array}{c}\text { Government, } \\
\text { corporations }\end{array}$ \\
\hline $\begin{array}{c}\text { What are the key } \\
\text { guidelines for ethical } \\
\text { behaviour? }\end{array}$ & $\begin{array}{c}\text { Negotiated legal } \\
\text { framework of business }\end{array}$ & $\begin{array}{c}\text { Corporate codes } \\
\text { of ethics }\end{array}$ & Managerial discretion \\
in busines ethics? & $\begin{array}{c}\text { Social issues organizing } \\
\text { the framework of } \\
\text { business }\end{array}$ & $\begin{array}{c}\text { Misconduct and } \\
\text { immorality in } \\
\text { single decisions } \\
\text { situations }\end{array}$ & $\begin{array}{c}\text { Corporate governance } \\
\text { and acountability }\end{array}$ \\
\hline $\begin{array}{c}\text { What is the dominant } \\
\text { stakeholder } \\
\text { management approach? }\end{array}$ & $\begin{array}{c}\text { Formalized multiple } \\
\text { stakeholder approach }\end{array}$ & $\begin{array}{c}\text { Focus on } \\
\text { shareholder value }\end{array}$ & $\begin{array}{c}\text { Implicit multiple } \\
\text { stakeholder approach, } \\
\text { benign managerialism }\end{array}$ \\
\hline
\end{tabular}

Source: Crane A., Matten D., (2010), Business Ethics. Managing Corporate citizenship and Sustainability in the Age of Globalization, Oxford University Press, p. 26

\subsection{Business Ethics in Latin America}

The paradigms of business ethics in Latin America can be synthesized as: promoting integrity in companies, creating competitive and "healthy" organizations, improving ethical issues as a higher value, developing a social environment based on ethical values. Two terms describe very well the ethical issues of business in Latin America: integrity and social responsibility (Aruda, 1997). The same author describes the many problems in the countries in this area, such as the high level of corruption, low ethical standards in politics, materialism and overconsumption, as well as a disconnection between the values expressed by the Catholic Church and business practices.

\section{Conclusions}

Certain ethical standards and values are accepted in all societies, and the golden rule "as you would like them to do to you, do them to them" (Bible, Luke 6) appears in the teachings of each major religion (Treviňo and Nelson, 2011). These aspects suggest a basis for a common understanding in different cultures, but the interpretation of values differs from one culture to another. Fairness is a universal value, but beliefs about what is right varying from one country to another.

Studies have revealed important international differences in ethics policies, and cultural values are an important determinant of these (Scholtens and Lammertjan, 2010). Ethical practices that are suited to a particular culture can negatively 
influence the understanding of organizational and social life from another cultural context. Future research should extend to the influence of other cultural dimensions on the perception of business ethics, but also on the concrete application of the various codes of conduct and ethics in the business environment.

An interesting aspect is the perception of employees from multinational companies about the source of the ethical initiative, whether it comes from the culture where the headquarters are located or is an initiative of a subsidiary. Moreover, if the degree of homogeneity of national cultures is low, domestic firms may face ethical problems similar to those of multinational companies.

Under these circumstances, managers need to become increasingly aware of the ethical values of the cultures that their organization comes into contact with in order to achieve success in an increasingly competitive global environment. An increasingly important role will be played by managers and professionals in human resources, as they are responsible for informing and directing ethical decisionmaking processes and need to develop their ability to cultivate an ethical culture of business. It is advisable for them to conduct ethical perceptual studies in their own company to have a clearer picture of the training needs of employees in this direction.

Future research should extend to the influence of other cultural dimensions on the perception of business ethics, but also on the concrete application of the various codes of conduct and ethics in the business environment.

In the case of multinational corporations and beyond, it is necessary to adopt codes of ethics that are in line with the company's mission and system of values but also reflect legal regulations, moral aspects and some habits that are specific to the countries where those companies are active.

An important challenge for the academic environment will be to propose a theory that explains the mechanism of interaction between culture and ethics.

Although the issue of the link between culture and ethics has been addressed in many situations and contexts, it seems that it has not yet been fully clarified and will require attention in the future.

\section{References}

1. Ardichvili, A., Jondle, D., Kowske, B., Cornachione, E., Li, J., Thakadipuram, T., (2012), Ethical Cultures in Large Business Organizations in Brazil, Russia, India and China, Journal of Business Ethics, 105, pp. 415-428

2. Aruda, M.C., (1997), Busines Ethics in Latin America, Journal of Business Ethics, 16, pp. $1597-1603$

3. Berger, R., Herstein, R., (2014), The Evolution of Chinese Business Ethics, Management Research Review, Vol. 37, No. 9, pp. 778-790

4. Burduş, E., (2004), Management comparat internaţional, Ed. Economică, Bucureşti 
Isac F.L., Remes E.F. (2017)

Culture and business ethics - a comparative perspective

5. Carroll, S.J., Gannon, M.J., (1997), Ethical Dimensions of International Management, SAGE Series on Busines Ethics

6. Chaterjee, S., Pearson, C., (2003), Ethical perception of Asian managers: evidence of trends in six dvergent national contexts, Business Ethics: A European Review, 12, No. 2, pp. 203-211

7. Cho, E., (2009), Work Values and Business Ethics in Korea, Advances in Developing Human Resources, Vol. 11, No. 2, pp. 235-252

8. Choi. T.H., Nakano, C., (2008), The Evolution of Business Ethics in Japan and Korea over the last decade, Human Systems Management, Vol. 27, No. 3, pp. 183-199

9. Crane, A., Matten, D., (2016), Business ethics. Managing Corporate citizenship and Sustainability in the Age of Globalization, fourth edition, Oxford University Press

10. Crăciun, D., Morar, V., Macoviciuc, V., (2005), Etica afacerilor, Ed. Paideia, Bucureşti

11. Deephouse, D.L., Newburry, W., Soleimani, A., (2016), The Effects of Institutional Development and National Culture on Cross-National Differences in Corporate Reputation, Journal of World Business, 51(3), pp. 463-473

12. Hofstede, G., Hofstede, G.J., Minkov, M., (2012), Culturi şi organizaţii. Softul mental, Ed. Humanitas, Bucureşti

13. Hood, J.N., Logsdon, J.M., (2002), Business ethics in the NAFTA countries: A cross cultural comparison, Journal of Business Research, 55, pp. 883-890

14. Iamandi, I.E., (2012), Etică şi responsabilitate socială corporativă $\hat{\imath}$ afacerile internaţionale, curs Master Afaceri Internaţionale, ASE Bucureşti

15. Ionescu, Gh.Gh., (1997), Cultura afacerilor. Modelul american, Ed. Economică, Bucureşti

16. Liedekerke, L.V., Dubbink, W., (2008), Twenty Years of European Business EthicsPast Development and Future Concerns, Journal of Business Ethics, 82, pp. 273-280

17. Mele, D., (2008), Business Ethics: Europe versus America, in Leadership and Business Ethicsed. G. Flynn, pp. 13-27, Dordrecht, Springer

18. Palazzo, B., (2002), US-American and German business ethics: an intercultural comparison, Journal of Business Ethics, 41, No. 3, pp. 195-216

19. Popa, I., Filip, R., (1999), Management internaţional, Ed. Economică, Bucureşti

20. Scholtens, B., Lammertjan, D., (2007), Cultural Values and International Differences in Business Ethics, Journal of Business Ethics, 75, pp. 273-284

21. Taka, Iwao, (1997), Business Ethics in Japan, Journal of Business Ethics, 16, pp. 14991508

22. Tam, O., (2002), Ethical issues in the evolution of corporate governance in China, Journal of Business Ethics, Vol. 37, No. 3, pp. 303-320

23. Tînjală, D.M., Pantea L.M., Buglea, A., (2015), Business Ethics and Integrity. A Case Study on 300 U.S. Listed Companies, Studia Universitatis "Vasile Goldis" Arad. Economics Series, Vol. 25, Issue 2, pp. 63-80

24. Treviňo, L.K., Nelson, K.A., (2017), Managing Business Ethics. Straight Talk About How To Do It Right, seventh edition, John Wiley and Sons

25. Verstegen Ryan, L., (2005), Corporate Governance and Business Ethics in North America: The State of the Art, Business \& Society, Vol. 44, No. 1, March, pp. 40-73 
Isac F.L., Remes E.F. (2017)

Culture and business ethics - a comparative perspective

26. Weaver, G.R., (2001), Ethics Programs in Global Businesses:Culture's Role in Managing Ethics, Journal of Business Ethics, 30, pp. 3-15

27. Weber, M., (1993), Etica protestantă şi spiritul capitalismului, Ed. Humanitas, București 